\title{
The Conditions of Parenthood in Organisations: An International Comparison*
}

\author{
ALENA KŘÍŽKOVÁ, HANA MAŘíKOVÁ, \\ RADKA DUDOVÁ, ZDENĚK SLOBODA** \\ Institute of Sociology AS CR, Prague
}

\begin{abstract}
The paper focuses on organisations and the conditions for working parents in terms of combining work and care and how those conditions are set up and negotiated in organisations. The research draws on three case studies comparing pairs of companies active in the Czech Republic and in one of the following countries - Germany, France, and Sweden - in the field of engineering. The goal is to explore in depth the conditions that Czech working parents are faced with and that derive from the organisational processes and means and dynamics of negotiating conditions for working parents, and to compare them with the conditions in other countries and identify the sources of variability of these conditions. Important differences between a company's family-friendly practices in its home country and in its Czech branches are primarily determined by the differences in the way in which welfare regimes are set up in individual countries. In addition, the authors identify the following five main interlinked factors explaining the variability of family-friendly policies and practices in organisations: parental (maternity) ideologies, the organisational culture of non-discrimination and equal opportunities, the actors' activity in work relations, the role of trade unions in negotiations, and the given organisation's experience with employees-parents.
\end{abstract}

Keywords: organisations, family-friendly policies, work, gender

Sociologický časopis/Czech Sociological Review, 2009, Vol. 45, No. 3: 519-547

\footnotetext{
* This article was written as part of the research projects: 'Work-Life Balance from the Perspective of Gender Relations and Social and Employer Policies in the Czech Republic' (grant no. 403/05/2474), funded by the Czech Science Foundation, 'Support for the Social Acceptance and Effective Enforcement of Gender Equality in the Public Sphere' (grant no. 1QS700280503), funded by the Grant Agency of the Academy of Sciences of the Czech Republic, 'Processes and Sources of Gender Inequalities in Women's Careers in Connection with the Transformation of Czech Society after 1989 and with the EU Membership of the Czech Republic' (grant no. IAA700280804), funded by the Grant Agency of the Academy of Sciences of the Czech Republic, and 'Constructions of Breadwinning in Czech Society after 1989' (grant no. GA403/09/1839), funded by the Czech Science Foundation.

** Direct all correspondence to: Alena Kř́žžková, Hana Maříková, Radka Dudová, Zdeněk Sloboda, Institute of Sociology AS CR, Jilská 1, 11000 Prague 1, Czech Republic, e-mail: alena.krizkova@soc.cas.cz, hana.marikova@soc.cas.cz, radka.dudova@soc.cas.cz, zdenek. sloboda@soc.cas.cz.
}

(C) Sociologický ústav AV ČR, v.v.i., Praha 2009 


\section{Introduction}

Demographic changes and changes in European labour markets have increased the need for European societies to address the issue of work-life balance and to introduce family-friendly policies. A typology of the ways and variations in which individual countries deal with this issue has stirred a major debate in sociology [Esping-Andersen 1990, 2000; Orloff 1993; Lewis 1992]. However, the issue of family-friendly policies and practices at the level of organisations and how they are intertwined with the policies of individual countries has received much less attention in sociological research.

In this article, we focus on organisations, the conditions for working parents trying to combine work with caring for their children, and how these conditions are created and negotiated in organisations. Our research is based on three case studies comparing pairs of companies active in the Czech Republic and in Germany, France, or Sweden, operating in the field of engineering. The goal is to explore in depth the conditions that Czech working parents are faced with and that derive from the company's organisational processes and the means and dynamics of negotiating conditions for working parents. We chose to conduct qualitative sociological case studies as the method of achieving this goal. Case studies of companies that operate in several countries give us the opportunity to capture the links between the level of state social policy and the level of policies and practices in organisations.

The basic premise of this article is that family-friendly policies and practices in organisations and the working conditions for working parents are not and cannot be identical or similar within one company operating in two countries because they are crucially influenced by state social policy. The goal of the paper is to suggest a potential answer to the related questions: 'What is the source of variability in family-friendly policies and practices in organisations, and what other influences give rise to this variability on top of state social policy?'

The research was also intended to reflect upon another dimension of the contemporary labour market - the injection of foreign capital into Czech companies and the operations of branches of foreign companies in the Czech Republic. We questioned whether and how the policy of a Czech company changes when foreign capital becomes dominant or when a foreign owner buys a company and thus becomes the buyer's subsidiary. In what ways do the working conditions for working parents differ in the different branches of one company operating in two countries?

In order to find answers to these questions, we selected two companies that have a long tradition of operating abroad within Europe and that in the past decade established distribution branches and began operating in the Czech Republic (see case studies 3.2. and 3.3. below). We selected one company in the same industry that had a long history of operating in the Czech Republic as the largest production and distribution firm in its field and was then taken over by a foreign owner, thus creating an international concern (see case study 3.1. below). 
In the first and theoretical part of the text, we start with welfare state classification theory and feminist arguments for the introduction of the gender dimension, especially those focused on family-friendly policies. Then we turn to the organisational level and to how policies, practices, and working conditions for working parents are gendered. In the second part, we discuss the methodology of the case studies used in our research. The third part presents the individual case studies, which compare the organisational environment of the Czech and the home branches of one company. In the fourth part, we discuss our findings. The article closes with a summary of the main findings and suggestions for future research.

\section{State welfare policy}

A family-friendly policy can be defined as a formal or informal set of terms and conditions that are designed to enable an employee to combine family responsibilities with employment and reduce job-family conflict. They can be categorised into: paid or unpaid leave arrangements (e.g. maternity, parental leave), flexible working arrangements (e.g. part-time, job share, flexitime, compressed working week, annualised hours, and homeworking), and workplace facilities (e.g. nurseries, subsidised childcare, and counselling or stress management provision) [Callan 2007: 674; cf. Davis and Kalleberg 2006: 192]. The reasons and arguments for implementing family-friendly policies are framed in two ways: first, in the sense that gender equality and equality of opportunities together with economic factors such as the implementation of these policies can be profitable, and not just in terms of bringing about equality [Lewis 2006; Gornick and Meyers 2008] and second, in purely economic terms [Callan 2007].

Welfare state theories that build on democratic values, including gender equality in opportunities and treatment, construct an adult worker model [Lewis 2001] or a worker-parent model [Leira 2002], which must be free from gender stereotypes. Each individual should be able to choose his or her own strategy for combining work and care so that no type of choice is penalised. In order for carers and parents, women and men, to be able to equally choose the degree of their involvement in paid and unpaid labour, it is necessary to put in place a mixture of policies relating to time (working hours, time for work, time for care), money (for purchasing care and supporting those who personally provide care), and services (for children and for the sick and the elderly) [Leitner 2003; Pfau-Effinger 2005; Bettio and Plantenga 2004; Lewis 2006: 111].

Analyses of welfare states and inequalities completely ignored the gender dimension up until the end of the 1980s [Fraser 1989; Lewis 1992; Orloff 1993]. According to Esping-Andersen's classification, Germany and France are defined as corporatist welfare states and Sweden as a social democratic welfare state. Walter Korpi included the gender dimension in the Esping-Andersen analyses and modified the types. He categorises France and Germany as general family-sup- 
port model and Sweden as the dual-earner support models [Korpi 2000]. EspingAndersen himself later changed his viewpoint and paid significant attention to women's employment [Esping-Andersen 2000: 23].

Arguing from the stance of feminist social policy, Jane Lewis criticised Esping-Andersen's complete neglect of the gender dimension and instead categorised welfare state regimes based on the gender division of labour [Lewis 1992]. Furthermore, Lewis drew attention to the fact that gender is a fitting analytical tool thanks to its historical dynamism. Thus, for example, France historically ranked among the strong male-breadwinner states and today, according to Lewis, ranks together with Germany among the modified male-breadwinner countries. Sweden, according to Lewis, is a typical example of a weak male-breadwinner model. Shortly afterwards, Orloff divided the gender aspects of welfare states into two dimensions - women's access to paid employment and women's capacity to create and maintain an autonomous household [Orloff 1993]. Women's access to paid employment is a dimension that is strongly linked to the position of women in society as a whole and to attitudes towards the role of mothers in the public arena.

Feminist analyses of welfare states have also pointed out the limitations of all these typologies because they neglect very important differences, grouping together countries that are vastly dissimilar, like Germany and France. Research studies comparing individual countries from various perspectives (in our case family-friendly employment policies) further illuminate the causes of differences and their inter-relations. Furthermore, with the enlargement of the European Union, the question arises of how to categorise new member states in the existing typologies or whether to completely revise these typologies. However, the effort to categorise new member states has only just begun [Pascall and Kwak 2005]. The inclusion of the Czech Republic in a comparison with three Western European countries can provide a significant contribution to this body of knowledge.

After 1989, the Czech Republic, on its path to capitalism, abandoned some of the state family policies it previously had that supported working parents (especially mothers), such as its wide network of nurseries providing infant care, and it implemented the extension of parental leave, the effect of which has been the long-term exclusion of women from the workplace. Legislative measures of family policy and the labour market which frame the strategies and create the space for work-life balance have changed dramatically in the last fifteen years. The following changes in particular have occurred: a) the introduction of parental leave, which both parents can take up as agreed between them; b) the gradual extension of maternity and parental leave to up to three years (until the child is three years of age), along with the possibility of collecting a low flat-rate parental allowance for up to four years; c) granting fathers equal access to parental and maternity leave in relation to the protection of employee rights; d) the introduction of the option of unrestricted earnings while a parent is collecting parental allowance and is on parental leave. (For a detailed account of the current legislative terms that apply to parenthood, see Maříková [2005]; and on their development and uptake by parents and employers in the Czech Republic, see Kuchařová et al. 
[2006]). The terms under which the legislative measures of the state family policy are taken up are negotiated at the level of organisations and within their gender structure and organisational culture [Křížková and Vohlídalová 2009].

The availability of institutional childcare facilities for children under the age of three is minimal and even among parents with children aged three or four the demand for childcare services is not met. In practice, this means that most women opt for parental leave of a maximum of three years. Some changes have occurred, such as the possibility to collect parental allowance and engage in gainful employment simultaneously. However, the practical exercising of this option is hindered by the rigidity of the labour market, which does not make it possible (or only marginally) to make use of legislative measures such as part-time work or homeworking.

For our comparative study we selected companies based in Germany, France, or Sweden that have branches operating in the Czech Republic. These four countries were selected because they differ significantly in terms of how their social policy is constructed.

\section{Organisation policy}

The basic form and structure of modern organisations, which was established with the rise of modern capitalist societies, has always corresponded with the roles of men at a given period in history. The model worker was a man free from the concerns of family life, which was strictly separated from the sphere of labour. Family life was the responsibility of women, who did not contribute significantly to the operation of organisations, or else they performed service and caring roles there as they did in the household. With the mass entry of women into the labour market, organisations, and enterprises, women largely had to adapt to the model of worker that matched the life roles of men [Wajcman 1998]. These gender regimes, which are typical of the general inequalities in the position of women and men in organisations [Connell 2002], are largely maintained and reproduced in contemporary organisations, despite the existence of gender equality policies [Křŕžková 2003]. Women tend to be concentrated at the lower levels of the organisational hierarchy and in positions and professions with worse conditions (lower wages, prestige, promotion opportunities, access to further training, benefits, etc.)

Joan Acker's description of 'gendered organisations' outlines the gender differences and inequalities that permeate the whole organisational structure and all its processes [1990]. Acker claims that '[W]ork organizations are critical locations for the investigation of the continuous creation of complex inequalities because much societal inequality originates in such organizations' [Acker 2006: 441].

In this study, we deal with how these various organisational gender regimes - which are the result of various influences, such as state welfare policy, the degree of labour market regulation, the degree of centralisation of negotiations on labour 
conditions (national, union, entrepreneurial and individual levels), and the meanings and practices of work and care and attitudes to the gender division of labour in a concrete country [Orloff 1993; Lewis 1997; Ellingsæter 2000] form the organisational environment, policies, and practices for combining work and family life.

For this study we have selected engineering as our one field of business. This type of industry and the individual segments of it, especially production lines, workshops, and plants, tend to be viewed as 'masculine' and perceived as a 'man's world' or more precisely as social environments that embody masculine values, norms, visions, and the male perception of the world and principles of activity, etc. [Cockburn 1985]. This does not necessarily mean that the jobs in this industry are always and under all circumstances performed by men, but men do predominate in this segment of production, among blue-collar workers, and among designers, constructors, engineers, and, last but not least, among managers. The masculine gendering of the organisation is linked to this symbolic level and a priori signifies the exclusion of everything that is not connoted as 'male' (or masculine) and that is then considered to be 'female' (or feminine) in the binary gender optic.

The gendering of the field of engineering thus revolves around the concept of traditional masculinity [Connell 2002]. In view of the fact that in the binary gender optic family-friendly policies tend to be perceived as measures designed for women, the choice of a 'masculine' field presents a suitable environment for studying family-friendly organisational policies and practices, in part also because it is an environment that is not typically perceived as one that would implement such policies and practices.

\section{The methodology used in the case studies of the engineering firms}

Three case studies were carried out in three organisations whose parent companies are based in one of the countries of the 'old' European Union (EU 15) - Germany, France, Sweden - with a subsidiary in the Czech Republic. These companies are all prominent in the field of engineering.

The research was conducted at the end of 2006 and the start of 2007 using semi-structured interviews with the same thematic outline in the parent company and its Czech subsidiary. The interviews were conducted with human resources staff, representatives of unions, and with employees-parents of young children. The German and French interviews were conducted in the respondents' native language, and for Sweden, the interviews were conducted in English. The analysis of the transcribed interviews was also conducted in these languages.

The interviews were all conducted according to the same script outlining the thematic areas to be covered during the interview, but the actual order and the exact wording of the questions changed depending on the context and the course of the interview. Moreover, the interview was accompanied by a brief questionnaire, the purpose of which was to map individual family-friendly measures offered by 
the organisation. Data collection was supplemented with the study of documents that were made available to us during the interviews and through contacts within the organisations. Relevant documents concerning family-friendly policies and programmes or collective agreements made it possible for us to gain insight into the range of institutionalised measures adopted. ${ }^{1}$

The main analytical instrument used in the data analysis was the continuous comparison of the emerging categories and their dimensions, both within one case study - within the framework of one subsidiary of a company and between the subsidiaries of that one company in two countries - and between the case studies themselves. During the analyses we compared the results of the individual case studies and developed a common set of codes, which directed the analyses so that the findings were to at least some degree comparable.

In view of the fact that the methodological framework of this research is in grounded theory and social constructivism, it was not our goal to obtain strictly comparative results. Consequently, our results include three case studies of companies, each of which compares the Czech and the parent organisation.

The size and nature of the organisation in the Czech Republic was of significance. For example, the German company has its distribution headquarters and a production branch in the Czech Republic, so it is quite independent in terms of its production and marketing operations. However, the French and Swedish firms only have distribution headquarters in the Czech Republic, so it is mainly marketing that is carried out in the Czech Republic. This had a bearing on the choice and availability of individual communication partners in the organisations, but also on our 'knowledge framework'. Because of these differences, in the case study of Germany and the Czech Republic we opted for a comparison of the organisations as a whole - the production and administrative components. In the case studies comparing the Czech Republic with Sweden and France we opted for a comparison of only the administrative parts of the organisations. Those differences may account for some of the findings; therefore, we have taken them into consideration when interpreting the data.

Access to the field was another limitation to the study. In the German engineering firm case, we were able to interview one human resources staff member, one trade union representative, who is also a member of the works council, and two parents from the German controlling company; in the Czech subsidiary we interviewed two human resources staff members, one trade union representative, and three parents (two mothers, both in marketing, and one father, a single parent in a blue-collar profession).

In the French engineering firm case, we conducted seven in-depth interviews in the controlling company (one with a female representative of the human resources department, one with a male representative of the trade union, and five with male and female employees-parents). Despite repeated attempts to establish

1 A detailed account of the data sources, especially the interviews we conducted, is contained in the footnote to each of the case studies. 
contact the human resources department at the Czech firm refused to cooperate with us and we were only able to carry out two interviews with female employees, both of them mothers of small children.

In the case of the Swedish engineering firm, the managerial staff (at the Swedish headquarters) proved to be even more uncooperative. We managed to conduct one interview with a young woman in a managerial position in administration before she left for parental leave. In the Czech branch we interviewed three employees-parents: one man in the position of the company director, one man in the position of a customer service official, and one woman in a middle management position.

In the Czech branch of the French company and at the Swedish company headquarters we were given limited access to the respondents, and that could hinder the comparative potential of the studies. Nevertheless, we were able to obtain formal and informal supplementary information from our study of documents and through our personal contacts in the companies.

\section{No two organisations are alike: foreign companies in the home and in the Czech environment}

This section outlines the similarities and differences between the environment of the parent company and that of its Czech subsidiary. The case studies are introduced with a brief summary of the given country's welfare state policy compared to that of the Czech Republic, followed by a comparison of how the company operates in each of the two different countries and a comparison of their corporate cultures.

\section{Germany and the Czech Republic ${ }^{2}$}

In the Federal Republic of Germany a new parental allowance, the 'Elterngeld', was introduced on 1 January 2007, which replaced the existing way of supporting persons on parental leave. The parental allowance is designed to motivate the faster return (especially of women) to work and to motivate men to take at least

\footnotetext{
${ }^{2}$ In the Czech Republic the interviews were conducted with the human resources staff members, one in the field of top management and the other from the department of personnel services; with two mothers, one after maternity leave and the second newly on maternity leave, both in marketing, and lastly with a father who was a single parent in a blue-collar profession. Among representatives of trade unions, one respondent was a trade union member dealing with the issue of women and families. In Germany the interviews were conducted with a human resources staff member from the department of Frauenförderung (support for women and families), a female trade union representative and a member of the works council, a father who was on parental leave, and a mother of three shortly after maternity leave.
} 
some leave to care for a baby. The allowance is higher than the previous allowances and is designed to compensate for lost earnings. The allowance is paid in the first twelve months of the child's life and is equal to two-thirds of a person's salary (but with a maximum of EUR 1800). If the salary is lower than EUR 1000, $100 \%$ is paid out, but the absolute minimum amount is EUR 300. If the father goes on parental leave, this amount is also paid for the thirteenth and fourteenth months of the child's life. The parents can decide to collect the allowance for up to two years - but then only half of the monthly sum that would be payable to them during twelve (or fourteen) months is paid. The employing organisation is obliged under the law to keep the job position of an employee on parental leave open for them to return to.

A big problem in Germany (and even more so in its western part) is the major lack of preschool facilities. A law (from 2005) on the construction of childcare facilities stipulates that 230000 new places in kindergartens, nurseries, and daycare facilities are to be created by 2010. In addition to non-profit organisations, various ministries are currently addressing the issue of work-life balance.

\section{One company in various countries}

Both the German and the Czech organisations are comparable, though the Czech one is smaller. Both have headquarters in a smaller town and are the main employer (tens of thousands of people) in the town and its wider surroundings. Both the organisations are enterprises, with strong links to other industrial companies. They are successful, produce a large volume of exports, and make worldrenowned brands. Most of the organisations' employees work in production, that is, on the production line in a shift-based operation.

In the German organisation, our interviewees from the human resources department and trade unions voiced the need to build a 'family-friendly firm'; the works council also adopted such a resolution. The human resources department (Frauenförderung) in the organisation focused specifically on supporting women in the engineering environment and supporting families by providing information flyers and training for parents returning from maternity or parental leave.

Conversely, the Czech organisation maintains the very neo-liberal stance that 'the company should not be doing everything itself,... we allow people to earn enough...' so that they can take care of their own affairs (Miroslav; HRM, top management; 50 years of age; 2 children: 25 and 28 years of age; CR). In addition to the gendered opinions of Czech human resources managers about the impropriety of women working in an engineering company, another major difference compared to Germany was the huge influence that the individual shift managers and plants have on decision-making. This also affected the atmosphere within the organisation, especially in production occupations, where the largest number of people worked. Their decisions were guided both by gender biases and, ac- 
cording to a statement from a female trade union member, rudeness, along with efforts 'not to complicate one's life' by making concessions, such as modifying working hours or changing shifts, even if this was within their remit. Personal relations and 'camaraderie' with the boss also influenced decisions. However, in the parent company in Germany, human resources managers talked about their current efforts to attract more women to all types of work activities, to have more women in supervisory positions, and to attract girls from secondary schools into technical fields.

Shift work and line production are the most important factors that interfere in the implementation of family-friendly policies and practices. In both organisations, an administrative employee has to be present at the workplace for a fixed period of time but the start and finish of working hours are flexible. However, according to the statements of the human resources managers in the Czech organisation, flexible working hours are impossible in production. Similarly, there is a disparity in the Czech organisation with regard to part-time work: although officially permitted, part-time work does not exist in production. In the German organisation, part-time work is more frequently permitted in administration, but it is also possible to agree on a more flexible arrangement in production. Such an arrangement is negotiated with the shift or plant manager, but in practice it is relatively unusual.

The Czech organisation offers single parents a sheltered workshop where 'line work' is limited, and therefore some flexibility of working hours is allowed. However, the work is for lower wages, so, as one communication partner - a single father - noted, this is not a solution for single parents.

By comparison, the German organisation offers a special 'lunch' shift for single parents (from 10:45 to 16:33), which (unlike the protected workshop) is fully integrated into the main production process. When part-time positions and this special shift are not covered by internal staff, they are covered by agency staff. Agency workers are also used in the Czech organisation, but owing to reluctance on the part of the managers (the greater demands put on the manager's organisational efforts) it is not used for this purpose. A Czech human resources manager even declared that shortening shifts is impossible:

Well, it's simply not technically possible, it can't be... people go to work to fulfil tasks and not according to how they sleep or that they need to change a baby's diapers. (Ota; HRM, social services; 63 years of age; children: 31,38 ; CR)

Both organisations offer homeworking for office professions. While in Germany this is a practical working option, in the Czech Republic it exists only for those in top management. For the past two years, the German organisation has offered tele-working, but only a very small number of employees have taken up this opportunity. 
Company attitudes towards parenthood

Generally the interviewees did not regard taking maternity or parental leave as a problem. An important factor is the size of the organisation and the substitutability. The only perceived problem was in the case of a woman working in a specifically qualified position going on maternity leave. Both firms equally keep the position open for the employee on parental leave for longer than the legally defined period. In the Czech Republic, this is, according to the collective agreement, up to four years after a child is born (the fourth year is taken as unpaid leave); in Germany, an internal company decision allows up to seven years of parental leave.

Returning to work after parental leave in larger organisations appears to be less problematic in terms of finding a suitable position for a person to return to, especially in administrative posts. One Czech female trade-union representative noted that problems can, however, occur in production. According to her, 'the firm does not have a problem taking a person back but it has a problem employing them in another work regime.' (Dana; trade union employee; 54 years of age: children: 29, 33; $\mathrm{CR})$. She describes discriminatory practices where the firm offers the returning person a position but will not allow shift selection or part-time work, thus forcing the person (the vast majority of whom are women) to resign by agreement owing to difficulties with childcare responsibilities. The German organisation, on the other hand, does allow part-time work, even in line production.

In view of the fact that goods and technologies change fast, re-qualification upon return is common in both organisations. The German parent organisation even offers a 'family management' seminar for women/men returning from parental leave. The course prepares parents for the 'challenges' of combining work and parenthood.

Neither company offers many direct benefits to families. The Czech organisation pays a childbirth allowance; whereas other benefits (housing, health-care centre, etc.) were abolished upon the entry of the German partner in the 1990s. The German organisation does not provide a childbirth allowance. However, it offers parents an 'information service', such as an internet information exchange where it is possible to advertise and shop for babysitting services.

Babysitting and childcare are a major help to parents when combining family and working lives. Both companies previously had their own kindergarten or nursery. In recent years the parent company appears to have acknowledged the need to provide some childcare facilities to ensure employee satisfaction and it financially supports preschool facilities in the town. It also has a certain amount of influence over the services provided by the kindergartens and their opening hours. However, this is not the case in the Czech Republic. 
Parents' ability and room to negotiate

The interviewees' statements uncovered one major difference: the degree of in/ activity on the part of both the leadership of the organisations and parents. In Germany, parents were relatively well informed; they can ask for information (and do so) from the trade unions and the human resources department (Frauenförderung); in more qualified positions they are contacted by the human resources manager before they return from parental leave. As the German human resources manager says:

A woman coming back from parental [leave] knows what her rights are here. And in case of doubt, when human resources aren't willing to give it to her, she will go with them to the works council. (Maria; HRM, Dep. Frauenförderung; 47 years of age; 2 children: $15,17 ; \mathrm{DE})$.

Passivity on both sides is typical of the Czech Republic. Parents are generally unaware of their options and rights and are afraid to ask for anything, according to the female trade-union representative and a single parent-father. The human resources do not offer much because, allegedly, employees do not demand it (Ota; HRM, social services; 63 years of age). This creates a vicious circle. The organisation asks the employee but interprets silence as a lack of interest, and so it does not offer anything actively. Another argument heard from the organisation is the exaggeration of the effort not to discriminate; according to human resources managers, support for women, parents, or even kindergartens in the town would constitute discrimination against men, non-parents, or commuting employees.

\section{France and the Czech Republic ${ }^{3}$}

In France, a relatively short interruption of work after the birth of a child is well accepted, and collective childcare facilities have a good reputation. Furthermore, various types of care for children up to the age of three are relatively widely available (in terms of the number of vacant places and geographical availability), although this care can sometimes be quite expensive. Conversely, in the Czech Republic, childcare currently is insufficiently institutionalised and essentially unavailable. In France, a woman is entitled to sixteen weeks of maternity leave after childbirth, which can be extended by an additional four weeks. This period is covered by sickness insurance and, in many companies, collective agree-

\footnotetext{
${ }^{3}$ In the Czech branch of the French organisation we encountered negative attitudes on the part of the human resources department. We were even faced with efforts to prevent us from contacting employees for the purpose of getting an interview. It was also much more difficult (than in the French headquarters) to persuade the employees, male and female, to give us an interview.
} 
ments provide for coverage to make up for the rest of the salary. Parental leave can last up to three years after the child is born, during which the parent collects a low, flat-rate benefit. After childbirth, men are entitled to an eleven-day 'paternal leave', which $65 \%$ of fathers take up, and this is also covered by healthcare insurance. There is a cap on this benefit and some companies make up for the rest of the salary, like they do for mothers. This is also the case in the French parent organisation in the study.

\section{One company in different countries}

The French firm has headquarters close to Paris, with branches across the whole country. Its affiliates function in many European and other countries and it employs approximately 126500 people (December 2005). In the company there are very strong trade unions with a long history and great bargaining skills. These organisations work together when negotiating with management. The most important outcome of their activity in the past few years was the so-called 'Accord du 17 février 2004'. The agreement in many ways supplements a previous measure relating to work-life balance.

The Czech branch was established in 1993 and in 2007 it had 87 employees. It has its headquarters in Prague and deals especially in trade and production and spare parts distribution, though the company does not have any production units in the Czech Republic. Unlike the French headquarters, employees in the Czech company are not organised in trade unions.

The companies' respect for parenthood

The conditions for combining parenthood and paid work in both organisations derive mainly from the time spent at work. In France, the official working week is 35 hours; at the French headquarters, however, working hours were based on the employees' requests that instead of shortening the work day employees would be given an extra ten days in holidays. During the working day, French male and female employees at the headquarters spend a relatively long time at the workplace (nine to ten hours, but sometimes up to twelve hours). The headquarters offers an advantage in the form of flexible working hours: work starts between seven and ten in the morning and ends between four and eight in the afternoon or evening. In many ways, labour productivity in the managerial and administrative positions is still measured by the time spent at the workplace, which respondentsparents say does not work for them. The unwillingness of parents to spend long hours at work can thus have an effect on their career progression.

When you decide to give priority to the family and try to go home earlier, you have to suddenly accept a less interesting position. (Laure; HRM; 36 years of age; 2 children: 6 months, 6 years; FR). 
At the Czech branch, the rules governing working hours are somewhat different. Among the top managerial staff, a working day of ten hours or more is also sometimes expected, but this is not the rule. People in middle management positions usually start before nine in the morning and finish between five and six. Flexible working-hour arrangements are also in place here, with parents able to adapt them further to their needs:

Flexible, well, I have working hours stretched more than the normal hours. Because normally an employee should be here until five p.m. But I have an exception; I come at 7:45 and leave at 16:15 so I manage to fit my full-time job to the opening hours of a kindergarten. (Nad'a; business assistant; 31 years of age; 1 child: 5 ; CR)

Work-life balance can also be tackled through part-time work. In France, part-time work usually takes the form of four-fifths of the full-time equivalent (working four days a week). The main disadvantage of a shortened work load in France is that it closes the path to career progression. For career-oriented employees in positions of middle and top management, therefore, it is not a viable option:

In my opinion it is possible, but then they point their finger at you and your professional progression... is not maybe completely stopped but it stops for the time you are working part time. (Marie-Louise; product manager; 32 years of age; twins 16 months; FR)

In the first years of the child's life, part-time work can be a temporary solution.

The Czech branch is not as forthcoming when it comes to part-time work. Communication partners were able to use this type of work arrangement only in the first month after the enrolment of a child in a kindergarten or nursery as an adaptation period; otherwise it is not allowed, even in administrative positions.

In France, almost all women interrupt work because of childbirth. Female managers in the studied company usually stay at home with a child only during maternity leave or extend that period with proper leave. Thus, women usually stay at home until the fourth to sixth month after the birth of the child. According to the 2004 Accord, absence due to maternity leave should not have any influence on an employee's assessment. Nevertheless, this is not always the case, as one female representative of the human resources department explains:

I think that they are disadvantaged because there is a budget given for bonuses. Each department and branch has their own budget. And this budget must be divided. And of course a person who worked for the whole year gets more money. (Laure; HRM; 36 years of age; 2 children: 6 months, 6 years; FR).

Men in France are offered eleven-day paternal leave. Mr. André (business manager; 34 years of age; 2 children: 1, 3; FR) confirms that before the 2004 Ac- 
cord the attitude of the company to this type of leave tended to be negative - the company did not provide full salary compensation as it does now, and it did not look favourably upon men who decided to take up paternal leave. Since the 2004 Accord it has become widespread.

The Czech branch has thus far had little experience with female (or male) employees going on maternity or parental leave. Approximately five mothers with small children work there, of whom two are still at home with their child and do not plan to go back before the third or fourth year after the birth. Another employee, Nada, returned to work after being three years on parental leave, when the child enrolled in a kindergarten, which is a normal practice in the Czech Republic. Her experience with negotiating her return to work was not very good:

Otherwise, on the part of the HR, I have to say that there, although I announced long before that that I would like to come back and so on, and although I was saying already during maternity leave that I would like only to help someone for a few hours a week, to come back gradually, this was never considered. I have to say that the attitude was very, very bad, passive and even resistant. (Nad'a; business assistant; 31 years of age; 1 child: 5; CR)

Veronika, a manager, stayed at home with her child for fifteen months, after which she returned at the request of her direct supervisor. Personally, she feels this to be a long enough period, but in the Czech environment she had to deal with negative reactions from those around her, especially from women, because she failed to fulfil the cultural norm of 'good motherhood'. ${ }^{4}$

Parents' ability and room to negotiate

Owing to several decades of trade union bargaining at the French headquarters, actors (parents) do not appear to feel such a need to interfere actively in the negotiations; they see it as a process that takes place beyond them. In principle, bargaining in the French company is left to the trade unions, which carefully monitor the situation in the company. According to employees, trade unions are there to 'raise demands every time something comes up that can be improved from a social point of view.' (André; business manager; 34 years of age; 2 children: 1, 3; FR). Employees themselves do not usually demand anything from the leadership; the trade unions fulfil this role satisfactorily. They take care to distribute information - according to respondents it is sometimes difficult to get access to important information.

Whether and how parents (mothers) manage to find a balance between work and family obligations largely depends on social and institutional structures that help families. In France they have a wider range of childcare possibilities (state

4 Attitudes towards mothers who do not adhere to the norm of a mother staying at home for three years were studied in detail in [Janoušková 2004]. 
or private nurseries, day-care mothers, or household nannies) but they also have to battle with the excessive costliness of certified carers and the unavailability of places in state nurseries or the limited opening hours of these facilities. In the Czech Republic, state policy and the leadership of the organisation exhibit an overall disinterest in parents' problems obtaining day-care for children under the age of three.

Unlike the French headquarters, the Czech branch has no formal measures that go beyond what they are required to do by law. There is a general lack of experience with the issue of work-life balance. This is especially owing to the fact that the company almost exclusively employs young people (men and women), for whom the decision to start a family and consequently also the need to address the issue of combining work and private life are still in the future. The organisation has thus now been able to view its employees solely in the context of their work and without any outside commitments. The pressure to establish at least basic measures comes from the bottom up from female employees as they gradually become mothers and look for sustainable strategies to remain with the company. Success in negotiating clearly depends on their individual position in the organisation and their personal and professional relationship with their superiors.

\section{Sweden and the Czech Republic}

Measures for combining work and family have long been in place in Sweden. They are designed to ease the situation of families with minor children and are provided under the following legislation: the Act on Childcare Leave, the entitlement to part-time work or suitable modifications of working hours, the legal right of the child to qualified care through institutionalised care organised by the state or municipality.

In Sweden, a child's parents are altogether entitled to 480 paid days of parental leave (or ideally 240 days for each of them) which they can use for up to eight years after the birth of the child. Sixty days are allocated exclusively for each of them. Unlike the Czech Republic, then, there is a sort of 'parental quota'. Each parent has to use up this minimum leave period or the legal entitlement is lost. The use of this type of leave and the payment of the corresponding allowance during this time is set up in such a way to be as variable and flexible as possible in order for parents to be able to accommodate the demands and the needs of a

\footnotetext{
${ }^{5}$ In the text that follows we draw on analyses and work and map family policy in Sweden, on the Collective Agreement for the Engineering Industry in Sweden, and on the interviews we conducted. In the Swedish branch one interview was conducted with a young woman in a managerial position in administration before she left for parental leave; in the Czech branch interviews were conducted with three parents - a man in the position of a director in the company, a man in the position of a customer service official, and a woman in a middle management position who was on parental leave at the time the interview was carried out.
} 
child; furthermore, institutional barriers are eliminated to the greatest possible extent (in the social system setup) [cf. Saxonberg 2008]. The Swedish system aims to support a more equal distribution of activities between parents with the implementation of this measure.

Public day-care facilities for children of preschool age are affordable for all parents, with no one paying more than $3 \%$ of their (family) budget for the first child, $2 \%$ for the second, and $1 \%$ for the third or more children. Most childcare costs are paid from public sources in the form of contributions from the municipality and from state resources such as targeted grants and support, etc. For children between the ages of 6 and 12 inclusively, various leisure activities are organised during after-school hours in so-called leisure-time centres.

A system of preschool and school-age care with a universalistic design does not exclude parents with lower income or lower 'family' social capital, but integrates them on the basis of citizenship rights and creates equal space for the social employment of parents.

One company in different countries

The company under consideration in this study was established in the inter-bellum period, offering various types of services in a number of locations; today it is part of a supranational production company in the field of engineering. Although this sphere of production builds on masculine values and worldview, in the Scandinavian company under study, emphasis tends to be placed on the humanity of work and on interpersonal relations, teamwork and diversity of work teams, and equality and non-discrimination, which are considered to be the main principles of organisational operations. Measures within the company, which has thousands of employees in Sweden, are based on the principle of not excluding anyone $a$ priori and not preventing people from using their capabilities. Company measures respect the country's legislation and correspond to the generally widespread culture of non-discrimination.

Swedish law is very clear. There must be no discrimination of mothers, of either of the parents. During an interview no one may ask you about personal issues. These things are not acceptable either legally or culturally. Swedish culture in general is oriented against discrimination. (Ingrid; HR business partner; 33 years of age; no children; SE)

Within the company there is a strong focus not only on the person as an employee (good conditions are created to allow him or her to maximise their work performance) but also on people as individuals who have their own personalprivate-family life outside work.

In the Czech Republic, the branch is a small organisation with only a few dozen employees. It was established in the mid-1990s and imports products to 
the Czech Republic and conducts sales. Unlike the Swedish company there is no employee organisation (trade union) in the Czech firm. In the early days, a higher proportion of young people were employed in the firm who were at that time generally single and without children. There was a focus on high work performance; it was possible to identify 'loyalty' to the company, partly because of the aboveaverage wages. Given the average age of employees and that most of them were childless, the company did not have to deal with the issue of work-life balance, but that did not necessarily eliminate the issue of combining work and personal life altogether. However, the interviews conducted for this study showed that in the initial period the atmosphere in the company was very informal and friendly; employees were willing and got used to working overtime. It was not unusual to work from nine in the morning until ten in the evening, which undoubtedly left employees with a lack of free time - time for other people, relationships, and other activities than those immediately linked to the performance of paid work.

... When I came here, there was a huge number of young people. I was the oldest and I was just over thirty. The company was terribly immature in human terms... They didn't have families, they didn't have children. They placed work first... (Vojtěch; customer service director; 43 years of age; 2 children: 3,6 ; CR)

The companies' respect for parenthood

In the first years in which the Czech branch was being established, a work model was constituted that was 'tailored' to a certain type of worker. The worker was envisioned as a single person with no personal or family life or personal commitments and obligations towards others who are close and dependent on them. In this work model, an individual de facto cannot have any family commitments, or cannot fulfil these family commitments. This work model greatly interferes not only with family life but also with the personal life of the individual, including their ability to form personal relationships, as it becomes impossible for employees to (freely) use their leisure time. Unlike the Swedish parent organisation, the issue of work-life balance and the issue of equality was for a long time not a major topic for the management of human resources in the Czech branch.

In interviews with the Czech representatives of the company, it was noted that sensitivity to the needs of parents and especially mothers did not run along gender lines but according to whether an individual possesses such sensitivity or not. Nevertheless, the statement 'everything depends on people and their attitudes', which refers to informal, personally forthcoming solutions to the situation, reveals that the employer organisation does not have a standard institutionalised solution for work-life balance in terms of being more sensitive to employees with caring commitments.

While it is common in Sweden that a certain category of employees may have flexible work hours, work part-time, or work at home (especially employed mothers) because work organisation flexibility is ensured by a higher legal norm (the 
parents' right to these forms of work), these forms of work are not established in the Czech branch. It is also unusual in the Czech Republic for men to go on parental leave, ${ }^{6}$ which in the Swedish organisation they do in conformity with an internal document based on a higher-level Collective Agreement.

Our company philosophy is for men to be at home with children similarly to mothers. It is healthy for a family, and it is a good thing to be with your child. This is the reason the company supports this. (Ingrid; HR business partner; 33 years of age; no children; SE)

Parents' ability and room to negotiate

In view of the fact that at the time when the interviews were conducted, parents were in the minority in the Czech branch, there were no measures to specifically address their situation. Everything was based on personal negotiations: the need of the employed person to formulate their demands individually, the ability to enforce them, the ability to negotiate certain conditions for combining work and family. Again, the individual ability or inability of employees to assert their demands is related to the willingness or unwillingness of people who manage work teams to negotiate with an employee. Thus, the individual qualities of people in leadership positions (such as being forthcoming, tolerant, understanding or, alternatively, having a low degree of empathy, being unforthcoming, unfriendly, intolerant or a certain selective sensitivity and empathy to certain employees, etc.) and the power of their formal position are more important than written and impersonal rules.

Although some work-life balance measures are formally in place in the Czech environment, they do not necessarily function in practice because of the (small) size of the company and the dominant corporate culture, which is to a certain degree rigid. Poor tolerance for anything other than the 'usual' conduct in the given group (in this case, age group) weakens tolerance for otherness, for example, parents. It appears that there is an invisible dividing line between parents and non-parents in the company. In the Czech organisation there is low tolerance for other types of work organisation which is a result of an employee having a family, and this is more so on the part of co-workers than people in leadership positions.

I am definitely lucky that my boss, who has also two children, is a very family oriented person - according to me. So he always very well understood my situation. And the other fellow of mine also has a child. So, the willingness worked out there. However, as I could see in other departments, there have been mostly very young people, ambitious people who have not had a family. Therefore it is strictly required there to be at work until six, and even in another department I know that a colleague needed to get the mortgage signed and ... they were not helpful at all. (Monika; manager customer sales; 31 years of age, 2 children: 2 years 6 months, and 6 months; CR)

${ }^{6}$ For exceptions, for example, for families with caring fathers, see Maříková [2009]. 


\section{Discussion of the findings}

The three case studies gave us deeper insight into the issue of work-life balance from the perspective of working parents. The goal of the study was not to describe national systems of family policies or individual (family) strategies adopted by parents, but rather to focus on the level between these spheres of decision-making, and - against the backdrop of family policy systems in individual countries - to describe the conditions which organisations create and the ways in which these conditions are used by working parents to achieve work-life balance. Despite certain methodological limitations - problems with entry into some organisations - it is possible to derive some general conclusions from the study of the dynamics of the negotiations within the organisational environment and the links to the conditions determined by other social actors and individual strategies of parents in individual countries.

Despite our primary focus on the organisational level, our study also offers insight into individual levels of negotiating conditions for achieving work-life balance - the level of state family policy, the organisational level, and the individual level of an employee's strategy - especially in the Czech Republic [Kř́ižková et al. 2007]. En route to capitalism after 1989 the Czech Republic abandoned some of its previous state family policies that supported working parents (especially mothers). This resulted in the long-term exclusion of women from the work process and conserved gender stereotypical roles in the context of a two-income family. This is related to the current gender inequalities that exist in many walks of life in Czech society. At the same time, there was a dramatic decline in the amount of union organisation and the role of trade unions decreased. The discrediting of trade unions owing to the role they played during state socialism before 1989 is connected with the more general tendency to reject any more pronounced state interference. On the other hand, the Czech population still tends to accept conditions determined at the top, through legislation or by management, and does not question existing conditions or initiate activities themselves from the bottom up.

The comparisons between the parent organisations and their branches and between the three case studies permitted us to identify the main interlinked factors that explain the variability of family-friendly policies and practices in organisations:

\section{The character of the welfare state}

In this research it is important to realise that the four countries we selected differ significantly in terms of women's employment or more precisely in terms of women's access to paid employment [Orloff 1993]. As mentioned above, this dimension is one of the determining sources of the arguments to implement family-friendly policies in the labour market. The countries under study (the Czech Republic, Germany, France, and Sweden) can, from our perspective, be divided into two types. 
In the first type, state family policy basically excludes women after the birth of a child (by providing long parental leave ${ }^{7}$ and because of the unavailability of public childcare facilities for small infants) and thus conserves gender stereotypes related to care (by not supporting men to increase their participation in childcare); this is the way it is in Germany ${ }^{8}$ and the Czech Republic. This policy creates a certain opposition between the spheres of labour and family, employment and parenthood, work and care, and enforces the idea that labour and family roles are incompatible or in conflict. This is also related to the time demands on the performance of the roles in both these spheres - so-called presenteeism and pressure to work overtime, and high standards of motherhood in the form of the mother's extended presence at home - which support the assumption that work and parental roles are incompatible.

The second type of country, which includes France and Sweden, has long supported women's employment and maternal and parental leave is significantly shorter (six months to one year) and is accompanied by substantial financial compensation, which, together with a well-developed network of childcare facilities for the smallest children, ensures that women can return to work quickly. At the same time, family policy (at least in Sweden) gives considerable support to men in terms of contributing to care. The policies in these two countries are based on the concept of a working parent, more so in Sweden than in France, where there is a wide selection of benefits and services from which parents can choose depending on their employment position and income. Sweden is a country where the principle of universalism in social policy is firmly entrenched. This principle is founded on a high quality of services and supports individual rights compared to the countries of the first type (the Czech Republic and Germany), where social policy is largely based on the principle of subsidiarity and mutual dependence of family members, including support for the gendered division of labour at home. Our findings show that these provisions set by state social policies have consequences for the organisational cultures of individual companies in studied countries.

\section{Parental (motherhood) ideologies}

In addition to the character of the welfare state, there is a macro-level factor that is strongly linked to national welfare systems and has a major influence on the shape of the practices of the organisations. In terms of the differences discovered

\footnotetext{
${ }^{7}$ We should point out the absolute inappropriateness of the term for 'leave' in the Czech context. The Czech term 'dovolená' used in official texts and in normal parlance means 'holiday' in relation to parental work and care. It signifies the under-recognition and devaluation of this period of parenthood in Czech society, which is even embedded in law. We therefore suggest reconsidering the appropriateness of this term in the Czech political and linguistic contexts and finding a substitute for it.

${ }^{8}$ Germany has recently adopted changes geared at shortening parental leave, increasing financial compensation, and giving advantages to parents who share their care for a small infant by extending parental leave.
} 
among the individual countries, it appears to be crucial to examine the relationship between the length and conditions of maternity and parental leave and the ideology of motherhood, which sets the standards for a child's needs, especially in relation to the mother's uninterrupted presence or the length of the parental leave taken. These two variables differ hugely in the Czech Republic compared to the other countries in this study. Although a relatively precise notion of what it means to be a good mother is found everywhere, and this notion is considered to be universal, adherence to the French or Swedish standard would mean in the Czech Republic that a mother is neglecting her child and she could be viewed as a 'heartless' mother. The main difference between France or Sweden on the one hand and the Czech Republic on the other is the shorter duration of maternity and parental leave ${ }^{9}$ and the greater availability of high quality, trustworthy childcare services in the first two countries mentioned. Czech female managers cannot choose among childcare services but almost have to count on making use of private paid care. At the same time, they face condemnation from others if they terminate parental leave when their child is fifteen months old, which in France, for example, is not uncommon. The social policy system and childcare facilities and services in France and Sweden are clearly more developed than in the Czech Republic, which is reflected in the conditions of parenthood at the organisational level, especially in a situation when a Czech branch of a foreign company does not deal with the issue of employee work-life balance seriously.

'Motherhood ideologies' in fact stem from the gender division of labour. Czech society generally fits the modified male-breadwinner model [see Lewis 1992]: women leave the workforce for a relatively long period to care for small children and remain economically dependent on their partners. This situation lays the ground for numerous gender inequalities in the labour market as well as inside the family. 'Motherhood ideologies' [see, e.g., Duncan and Edwards 1999; Hays 1996] then serve as powerful rationalisations for these inequalities.

\section{The organisational culture of non-discrimination and equal opportunities}

Another key factor explaining the variability of the organisational practices across different countries is the extent to which the companies officially adhere to the politics of non-discrimination and equal opportunities. The Swedish welfare state is typical for its pro-active social and family policy with a strong emphasis on measures that allow women and men to achieve a balance between their work and extra-work commitments and obligations. This attitude is then reflected in the organisational culture of the Swedish parent company. To some extent, the situation in the French parent company is similar. If we compare the situation in

\footnotetext{
${ }^{9}$ Although the parental leave in France is set up similarly to the Czech Republic, it is supplemented with other measures allowing a greater variability in terms of ensuring childcare.
} 
the Swedish and French parent companies and its Czech branches it is clear that not everything that is taken for granted in Sweden or in France is implemented in the Czech Republic. This is due to the different legislative frameworks and the different influence of the culture and historical experience of each country in the study. Although some measures facilitating work-life balance are formally available in the Czech environment, they do not function because of the rigid organisational culture.

The Swedish firm in this study is founded on the principle of economic growth and organisational profit, not only in terms of production and sales but also in terms of the growth of the company's human capital. The firm stresses teamwork and the development and education of employees, as well as team diversity with a view to the level of skills, abilities, and qualities needed. Another component considered to be important for the development of the organisation is the support of women in leadership. The Swedish company strives to help eliminate inequalities between men and women through projects and measures aimed specifically at the sphere of gainful employment (such as career break programmes), but also through measures aimed at facilitating work-life balance. This 'women-friendly' organisational environment has a direct impact on the careers of women and on parents working in the Swedish and, to some extent also, in the French headquarters and the German company. In the Czech organisational units, attitudes towards women and parents are still conditioned by the tradition of coding engineering industry as a 'masculine' activity, which brings about the exclusion or denigration of everything coded as 'feminine'. This is usually automatically identified with the 'female sex' - either with an individual woman as a representative of the 'whole' or with women in general. This type of industry is thus dominated by 'masculine ideologies and instrumental rationality' [Kerfoot and Knights 1998], which rules out or renders impossible the adequate evaluation and use of other human abilities and qualities, including the employment of certain 'social' needs (such as thoughtfulness, safety, tolerance, etc.). The Swedish and the French cases show that this cultural coding can under specific conditions be made obsolete.

\section{Actors' activity in work relations}

The German, French, and Swedish parent organisations endorsed the European trend of supporting equal opportunities for women and men, work-life balance, and the 'family-friendly approach'. Representatives of Czech organisations, on the other hand, tend to maintain a gender-neutral approach, which is moreover marked by the fear that any benefit for parents could discriminate against everyone else. The organisational culture of (not) supporting equal opportunities for women and men is also related to the fact that the legal claims of parents to modify their working hours are more a matter of theory than practice in the Czech organisation, and it is often stated by the persons in charge that for opera- 
tional reasons it is impossible to implement certain measures. (The German organisation, however, was able to implement measures such as part-time work or changes in the length and organisation of shifts for parents in the same plants.)

In both Germany and the Czech Republic, it is apparent that people expect changes, directives, or initiatives to come from the state. This is especially obvious in relation to the issue of work-life balance, where conditions are viewed in toto as set by the state, and as such they are not disputed or are seen as accurate. This may also be related to the fact that in Germany and the Czech Republic the state family policy is basically uniform for all segments of the population and there are not many alternatives for creating an individual parental strategy, as is the case in France or Sweden. Although in terms of support for the family - whether by the organisation or the state - the situation in both the countries may look similar, our case study nevertheless shows that at the organisational level the situation in Germany is substantially different from the Czech Republic. Despite the fact that the company is a huge profit-generating concern, the offer and access of working parents to modifications in their working hours or to homeworking are more favourable in Germany. Generally, we could say that German employees are aware of many of their rights and opportunities. In the Czech organisation, employees are more passive; they are often unaware of what they could or should want from the organisation and also fear being too active. This paradoxically causes the organisation to give up on any effort to offer anything. The situation is similar in the Czech branches of the French and the Swedish companies: while in the parent organisations, negotiations (mainly taken care of by the trade unions) are an integral part of work relations, in the Czech branches there are almost no negotiations.

Joan Acker [2006] states that organisations are locations of the continuous creation of complex inequalities, where participants have different access to power and control over goals, resources, and outcomes, and that gender is one of the most important lines of construction of those inequalities. We can assume then that in the organisational environment, where the tradition of individual negotiation and claim-making is absent or underdeveloped (as is the case of the Czech branches of the studied companies), structural disparities and inequalities (including the lack of equal opportunities for parents) will be more persistent in character and there will be less chance of change.

\section{The role of trade unions}

In principle, the negotiation of working conditions, including work-life balance issues, at the organisational level in France (even more so than in Germany) is the responsibility of trade unions. In the Czech environment there are no formal measures in organisations that go beyond the framework established by law and unions do not exist. In the Czech branch of the Swedish firm (as well as in the branch of the French firm), there are no trade unions and the likely perception 
is that there is no need for trade unions. Moreover, there is no human resources manager at the corporate level and instead each individual manager partly performs this role himself or herself. Perhaps it is partly for this reason that there are no rules or employee conditions set for combining work and parenting roles. Apparent here again is the passivity of Czech employees, who are not active in asserting their demands, and the potential unwillingness of people in leadership positions to allow parents to opt for alternative working conditions. The Swedish firm, which is strongly focused on social issues, is family friendly, and stresses the equality of women and men, does not implement these policies with equal force in its branch organisation; and this is also the case in the French and German branches.

\section{The practical experience of the organisation with their employees as parents}

According to our findings, neither the Swedish nor the French companies transfer their family-friendly policies to the Czech branches of their companies but instead tend to 'take advantage' of the Czech entrepreneurial environment, which does not strictly adhere to legal measures. To some extent this could be owing to the fact, in the case of both companies, that it was established purely as an administrative-sales branch, which at the beginning employed only young, career-oriented men and women who have only recently begun to form their family strategies. They therefore have an absolute lack of experience with work-life balance issues, mainly owing to the size and composition of the organisation.

If we compare the attitudes and conduct of foreign companies in their home country and in the Czech Republic it is clear that what is normal in one country is not necessarily normal in another country. The supranational nature of a company does not necessarily eliminate 'local specifics'. In the Czech Republic we can discern a neo-liberal approach to work-life balance issues and employees' families, governed by the 'logic' that we let parents make money and let them take care of themselves. Conversely, in Germany, France, and Sweden the situation developed differently: the organisations seem to realise that a satisfied employee is an efficient and loyal employee. Therefore, they make efforts to listen to parents and actively improve their conditions, either by providing an information service or supporting preschool facilities, or through efforts to modify working hours for parents in such a way that they are able to combine their family and work commitments.

\section{Conclusion}

Important differences between the family-friendly practices of companies in their home country and in the Czech branches are due in part to the differences in the way welfare regimes are set up in individual countries. This is related to the gen- 
der structure of institutions at various levels in the given country and the area in which the company is active, differences in the importance of women's employment and motherhood ideologies, and the institutional conditions of childcare that the state (or other actors) offers. All this is influenced by the historical-social development of a country, which has an impact on the contemporary conditions of parenthood and newly implemented measures, because they are reflected in the way these conditions and instruments are conceptualised by individual actors - employers and parents, women and men.

The three case studies carried out in one industrial field allowed us to gain deeper insight into the organisational dynamics of the setting, negotiations, and practices of family-friendly policies in various countries compared to the Czech Republic. By using the given method in this area of research we were able to identify the following six main interlinked factors relating to the variability of family-friendly policies and practices in organisations: the concrete welfare policy setting (1), ranging between universalism and familiarism and creating the gendered frame for the operation of organisations; parental (motherhood) ideologies (2) as ideas about what constitutes 'proper' parenthood (motherhood), which, at the level of organisations and at the level of society, can facilitate the performance of parental (maternal) and working roles or aggravate and make impossible the performance of parental (paternal) and working roles in terms of attitudes and evaluations (which are also reflected in policies); the organisational culture of nondiscrimination and equal opportunities (3), which is a precondition for the willingness on the part of employers to offer and the ability of employees to take up family-friendly measures; the activity of actors (4) in work relations because, as we showed, at the level of organisations we can still discern a culture of employee passivity in terms of negotiating better working conditions, the unwillingness of employers to offer family-friendly measures and flexible working models, and the 'blind' acceptance of top-down measures by employees (from superiors) and employers (from the state); the role of trade unions (5) in negotiation working conditions and particular family-friendly policies at the organisational level; and finally it emerged that practical experience of the organisation with their employees as parents (6) is important for building a family-friendly organisational environment. To this we may also add the role of managers, which can be very important under certain conditions, as they often act as 'gatekeepers' with regard to the use of individual, formally offered measures or in terms of the development and implementation of employee demands. Simply put, an organisation with no trade unions, where most employees have no children, in a country where the welfare regime is not conducive to combining working and caring roles, will encounter great difficulty and reluctance on the path to developing family-friendly policies and practices.

The research study results show that, while a neo-liberal culture was imported into the Czech Republic with the influx of foreign companies and their economic and operational standards, so far they have not brought with them the social aspect that accompanies this culture in Western and Northern Europe. This discrepancy leaves room for further, more detailed study. 
ALENA KŘİŽKOVÁ is a senior researcher and head of the Gender \& Sociology Department at the Institute of Sociology of the Academy of Sciences of the Czech Republic. She is the author, co-author, and co-editor of books and articles on the issues of combining work and family life, gender inequalities in the labour market, organisations, management and entrepreneurship, and social citizenship. Alena Kř́žková also provides expertise to the European Commission as an expert on gender equality in employment and social inclusion.

HANA MAŘíKOVÁ is a researcher at the Institute of Sociology of the Academy of Sciences of the Czech Republic. She joined the Gender \& Sociology department in 1995. She specialises in sociology of gender and gender issues in the family with a focus on parenting, fathering, and gender identities. She is the editor, co-editor, and co-author of several publication on gender issues. She also teaches in the area of gender.

RADKA DUDOVÁ is working as a post-doctoral researcher in the Department of Political Sciences, FSW, Leiden University, and at the Institute of Sociology, Academy of Sciences of the Czech Republic. Her research interests are policy-making on abortion in the Czech Republic, the changes in private and family life accompanying the political and economic transformation in the Czech Republic, and parenthood after marital separation.

ZDENĚK SLOBODA received his masters in media studies in 2005 from the Faculty of Social Sciences, Charles University in Prague. From 2008 to 2009 he was a junior researcher in the Department of Gender \& Sociology at the Institute of Sociology of the Academy of Sciences of the Czech Republic. He is doing a PhD in sociology at the Faculty of Social Sciences, Charles University, in Prague, and simultaneously in media pedagogy/education at Leipzig University. He publishes and teaches in the area of gender and sexuality studies, media studies, education, and qualitative research.

\section{References}

Acker, J. 1990. 'Hierarchies, Jobs, Bodies: A Theory of Gendered Organizations.' Gender and Society 2: 139-158.

Acker, J. 2006. 'Inequality Regimes: Gender, Class, and Race in Organizations.' Gender and Society 20: 441-464.

Bettio, F. and J. Plantenga 2004. 'Comparing Care Regimes in Europe.' Feminist Economics 10 (1): 85-113.

Callan, S. 2007. 'Implications of Family-friendly Policies for Organizational Culture: Findings from Two Case Studies.' Work Employment Society 21: 673-691.

Cockburn, C. 1985. 'Caught in the Wheel: The High Cost of Being a Female Cog in the Male Machinery of Engineering.' Pp. 126-133 in The Social Shaping of Technology, edited by D. MacKenzie and J. Wajcman. Maidenhead: Open University Press.

Connell, R. W. 2002. Gender. Malden: Blackwell Publishers.

Davis, A. E. and A. L. Kalleberg. 2006. 'Family-Friendly Organizations? Work and Family Programs in the 1990s.' Work and Occupations 33: 191-223.

Duncan, S. and R. Edwards. 1999. Lone Mothers, Paid Work and Gendered Moral Rationalities. London: Macmillan Press. 
Ellingsæter, A. L. 2000. ‘Welfare States, Labour Markets and Gender Relations in Transition.' Pp. 89-110 in Gender. Welfare State and the Market: Towards a New Division of Labour, edited by T. P. Boye and A. Leira. London: Routledge.

Esping-Andersen, G. 1990. The Three Worlds of Welfare Capitalism. Cambridge: Polity.

Esping-Andersen, G. 2000. 'A Welfare State for the 21st Century.' Report to the Portuguese Presidency. 25 March 2008 (http://www.nnn.se/seminar/pdf/report.pdf).

Fraser, N. 1989. Unruly Practices: Power, Discourses and Gender in Contemporary Social Theory. Oxford: Polity Press.

Gornick, J. C. and M. C. Meyers. 2008. 'Creating Gender Egalitarian Societies: An Agenda for Reform.' Politics and Society 36: 313-349.

Hays, S. 1996. The Cultural Contradictions of Motherhood. New Haven, CT: Yale University Press.

Janoušková, K. 2004. 'Krkavčí matky?' (Unnatural Mothers) Pp. 16-48 in Obrazy dětství v dnešní české společnosti. Studie ze sociologie dětství, edited by I. Nosál. Brno: Barrister\&Principal.

Kerfoot, D. and D. Knights. 1998. 'Managing Masculinity in Contemporary Organizational Life: A “Man” agerial Project.' Organization 5 (1): 7-26.

Korpi, W. 2000 'Faces of Inequality: Gender, Class, and Patterns of Inequalities in Different Types of Welfare States.' Social Politics: International Studies in Gender, State E Society 7 (2): 127-191.

Kř́žková, A. 2003. 'Kariérní vzorce žen v managementu. Strategie žen v rámci genderového režimu organizace.' (The Career Patterns of Women in Management. The Conditions and Strategies of Women within the Gender Regime of Organisation) Sociologický časopis/Czech Sociological review 4: 447-468.

Kř́žzová, A. (ed.), Z. Sloboda, R. Dudová and H. Maříková. 2007. Podmínky rodičovství v podnikovém prostředí v mezinárodnim srovnání. (Conditions of Parenthood in the Business Sector in an International Comparison) Sociologické studie/Sociological Studies 07:9. Prague: Sociologický ústav AV ČR, v.v.i.

Kř́ž̌ková, A. and M. Vohlídalová. 2009. 'Rodiče na trhu práce: mezi prací a péči.' (Parents in the Labour Market: Between Work and Care) Sociologický časopis/Czech Sociological review 45 (1): 31-60.

Kuchařová, V., S. Ettlerová, O. Nešporová and K. Svobodová. 2006. Zaměstnání a péče o malé děti z perspektivy rodičů a zaměstnavatelů. (Employment and Caring for Small Children from the Perspective of Parents and Employers) Prague: VUPSV.

Leira, A. 2002. Working Parents and the Welfare State. Family Change and Policy Reform in Scandinavia. Cambridge: University Press.

Leitner, S. 2003 'Varieties of Familialism.' European Societies 5 (4): 353-375.

Lewis, J. 1992. 'Gender and the Development of Welfare Regimes.' Journal of European Social Policy 2: 159-173.

Lewis, J. 1997 'Gender and Welfare Regimes: Further Thoughts.' Social Politics 4: 160-177.

Lewis, J. 2001. 'The Decline of the Male Breadwinner Model: Implications for Work and Care.' Social Politics 8: 152-169.

Lewis, J. 2006. 'Employment and Care: The Policy Problem, Gender Equality and the Issue of Choice.' Journal of Comparative Policy Analysis: Research and Practice 8 (2): 103-114.

Maříková, H. 2005. 'Politiky, čas a peníze.' (Policy, Time, and Money) Pp. 22-34 in Kombinace pracovního a rodinného života v ČR: politiky, čas, peníze a individuální, rodinné a firemní strategie, Sociologické studie/Sociological Studies 05:04, edited by A. Kř́ǐzková. Prague: Sociologický ústav AV ČR.

Maříková, H. 2009. 'Pečující otcové: Příběhy plné odlišností.' (Caring Fathers: Stories Full of Diversity) Sociologický časopis/Czech Sociological review 45: 89-113. 
Orloff, A.S. 1993. 'Gender and the Social Rights of Citizenship. State Policies and Gender Relations in Comparative Research.' American Sociological Review 58 (3): 303-28.

Pascall, G. and A. Kwak. 2005. Gender Regimes in Transition in Central and Eastern Europe. Bristol: Policy Press.

Pfau-Effinger, B. 2005. 'Welfare State Policies and the Development of Care Arrangements.' European Societies 7 (2): 321-347.

Saxonberg, S. 2008. 'Právo na otce: Rodičovská “dovolená” ve Švédsku.' (The Right to a Father: Parental 'Leave' in Sweden) Pp. 125-143 in Práce a péče. Proměny rodičovské v České republice a kontext rodinné politiky Evropské unie, edited by A. Kř́žzová, R. Dudová, H. Hašková, H. Maříková and Z. Uhde. Prague: Sociologické nakladatelství.

Wajcman, J. 1998. Managing Like a Man. Women and Men in Corporate Management. Cambridge: Polity Press. 